\title{
TERMÉSZETI ÉS ANTROPOGÉN TÉNYEZŐK SZEREPE AZ ALSÓ-TISZA MENTI PARTFAL-INSTABILITÁSOK KIALAKULÁSÁBAN
}

\author{
KIS ÉVA-LÓCZY DÉNES \\ NATURAL AND ANTHROPOGENIC FACTORS GENERATING RIVERBANK \\ INSTABILITIES ALONG THE LOWER TISZA RIVER
}

\begin{abstract}
Bank erosion is a major driver a river channel processes worldwide. In the case of large meandering rivers, bend formation involves delicate patterns of undercutting and bank collapses. In the paper particularly high rates and diverse types of bank erosion are presented from the Hungarian section of the Tisza River, between Csongrád and Mártély. It is observed that geomorphic selfregulation (channel adjustments after channelization) have also been influential in channel evolution. When identifying the origin, mechanisms and types of mass movements along the riverbank natural geological (tectonic control, sedimentological buildup of banks and fluvial landforms) and hydrological (river regime and groundwater dynamics) factors are contrasted with anthropogenic factors (river regulation, other built structures on the bank), which are locally of equal significance. General predictions are given for the future occurrence of bank erosion, its expected frequency governed by weather patterns and opportunities for mitigation. On the basis of landslide hazard assessment using the modified Bank Erosion Hazard Index (BEHI), bank protection measures can be located in view of the ecology of the riparian zone. Structural interventions are only proposed where human structures are threatened by riverbank erosion.
\end{abstract}

Keywords: riverbank erosion, neotectonics, river regulation, bank morphology, BEHI index, sediment sequence, vegetation, Tisza River

\section{Bevezetés}

A folyómedrek fejlődésében a medermélyítésen kívül általában a partok eróziója is jelentős folyamat - különösen olyan, az üledékföldtani felépítésük és tektonikai preformációjuk következtében oldalirányban instabil medrek esetében, mint a Tisza magyarországi alsó szakasza.

Geomorfológiai értelemben a parti sáv a meder szegélye, a legkisebb és a legnagyobb vízállás közé eső felszínforma, amelyet éles perem határol vagy fokozatosan simul bele az ártér szintjébe (FLORSHEIM, J.L. et al. 2008). A parterózió több egymással szoros együttmúködésben múködő természetes folyamat együttes hatására következik be (HoOKE, J.M. 1979): a hordalék korráziós hatása „alámossa” a partot, majd a partfal instabillá válik és előbb-utóbb leomlik (CHURCH, M. 2000). Ebben a leomlásban nem mindig könnyú kimutatni a folyó tevékenységét, hiszen közvetlenül a parton táguló repedések okozzák (BRAVARD, J.P.-GILVEAR, D. 1996). A parterózió döntő mértékben hozzájárul a meder oldalirányú eltolódásához, a meanderek fejlődéséhez (pl. HASEGAWA, K. 1989).

A parteróziót befolyásolja a folyómeder mérete, a folyó vízhozama és esése, tehát energiája (COUPER, P.R. 2004), valamint medermintázata és hordalékszállítása (BENDA, L. et al. 2004). Jelentős az a hatás, amellyel a növényzet, a gyökerek fejlődése (ABERNETHY, B. 2000; Simon, A.-Collinson, A. 2002) befolyásolja a felszínformák stabilitását a meder környezetében. A partot anyagának mállása, illetve átnedvesedése (időjárási és talajvízhatások) is meggyengítheti (Lóczy D. 2005; BlanKA, V.-KISS, T. 2011). A vízzel telí- 
tett partok anyagában megnövekvő pórusnyomás (CASAGLI, N. et al. 1999) epizodikusan különböző típusú csuszamlásokat válthat ki. A mozgás legtöbbször apadáskor kezdődik, amikor a víztömeg oldalirányú megtámasztó hatása mérséklődik. (Vizsgált területünkön a folyó maximális vízszintingadozása mintegy 13 m.) Az instabilitást erősítik a szivárgó vizek, áramló talajvíz hatásai és az ezekkel kapcsolatos szuffóziós jelenségek is (CASAGLI, N. et al. 1999; LiNDOw, N. et al. 2009).

Ökológiai szempontból a folyópartok fontos határfelületek, amelyek a hidrológiai folyamatok hatására különösen erős dinamikát mutatnak (PIÉGAY, H. et al. 1997, 2005). A jelenlegi gyakorlat - és nem ritkán a helyreállítási stratégia is (BUIJSE, A.D. et al. 2000) az, hogy partbiztosítással, azaz strukturális beavatkozással féken tartsák a partpusztulást. Ennek természetesen létjogosultsága van mindenütt, ahol árvízvédelmi meggondolások, társadalmi javak, épített örökség megórzése (CHIN, A.-GREGORY, K.J. 2005) vagy a termőterület elvesztésének megakadályozása indokolják (PIÉGAY, H. et al. 1997; CASAGLI, N. et al. 1999). Ugyanakkor a folyóparti és ártéri ökoszisztémák fennmaradása szoros kapcsolatban van az ismétlődő eróziós és üledékképződési folyamatokkal (WARD, J.V.-STANFORD, J.A. 1995; STANFORD, J.A. et al. 1996), különösen a partokról elmosott finom üledékekre van szükség (EPA 2007). Az általánosan elterjedt, de bizonyítottan téves vélekedés szerint minden parteróziós folyamat egyértelmúen kedvezőtlen (FLORSHEIM, J.L. et al. 2008). Ez a felfogás vezetett a partvédőmúvek túlzott kiépítéséhez (MoNTGOMERY,D.R. 1997). A parti árvízvédelmi infrastruktúra élőhelyvesztéssel, a biodiverzitás csökkenésével, medermélyítő erózióval és egyéb ökológiai szempontból káros folyamattal jár (GREGORY, S.V. et al. 1991; WARD, J.V.-TOCKNER, K. 2001; NRC 2002; NAIMAN, R.J. et al. 2005).

Az Alsó-Tisza mentén továbbra is sok a nyitott kérdés az ártérfejlődés szakaszai, az ártérperem formaalakulásának története, valamint a partfalak, kanyarulatok és ártéri paleomedrek fejlődése tekintetében, amelyekkel kapcsolatban intenzív geomorfológiai vizsgálatok folynak (pl. SiPOS Gy. et al. 2009; KisS T.-HERnESZ P. 2011, 2015).

Jelen tanulmány célja a 2013 májusában bekövetkezett Alsó-Tisza menti sorozatos partfalcsúszások közvetlen okainak vizsgálata, a parterózió mértékének megállapítása nemzetközi irodalomból ismert index adaptálásával és azon helyszínek feltárása, ahol a parterózió reális veszélyt jelent a társadalom számára értékes objektumokra. A kiértékelés magyarázatot ad arra vonatkozóan is, hogy a Tisza menti sorozatos partfalcsúszásokkal egyidőben - a hasonló időjárási viszonyok ellenére - miért nem következtek be a Duna mentén is partfalcsúszások. Az index értékeiből az is kikövetkeztethető, hol szükséges partvédelmi intézkedéseket tenni, illetve hol kívánatos a parti élőhelyek minél természetesebb megőrzése - éppen a partfal viszonylagos stabilitásának fenntartása érdekében. A természetes és az antropogén beavatkozások (folyószabályozás) mint hajtóerők által kiváltott folyamatok közötti arány megállapítása segítheti a hatékony partbiztosítás tervezését (SCHWEITZER F. 2000; Schweitzer F.-NAgy I. 2011; SchweitZer F. 2015; Schweitzer F. 2017), ahol ez szükséges, az árvízvédelmet (Lóczy D. et al. 2009), olyan eljárások alkalmazását, amelyekkel a jövőben várható vízjárási szélsőségek káros hatásait is ki lehet védeni, figyelembe véve a parti sáv ökológiai viszonyait is (GILVEAR, D.J. 2000).

\section{A kutatási terület}

A tanulmányozott terület a közép-magyarországi ÉK-DNy-i irányú nagyszerkezeti vonaltól délre fekvő Tiszai nagyszerkezeti egység része (1. ábra) (HAAS J. et al. 2010). Fontos szerkezeti elem a Hódmezővásárhely-Makói-árok felé lehatároló vetô, melytől ÉK-re az aljzat a tengerszint alá, 7000 méterig süllyed. Az Alföld jelentôs része az ún. 


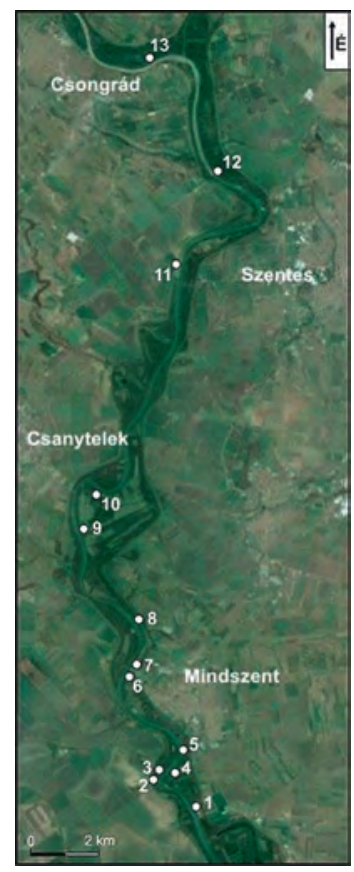

1. ábra A vizsgált partszakaszok helyei az Alsó-Tisza vidéken (alap: Google Earth) Figure 1 Locations of bank sections studied along the Lower Tisza River (base map: Google Earth)

„miocén domborzatfordulat” óta süllyed. A késő miocénre jellemző „nyugodt” süllyedést az Alföldön és a Kisalföldön felgyorsult süllyedés követte (HoRVÁth F. - CloETHING S. 1996). A vertikális mozgások sebessége mindenütt kisebb, mint 5 mm/év (HoRvátH F. et al. 2006), Joó I. (1992) szerint 1-2 mm/év (2. ábra).

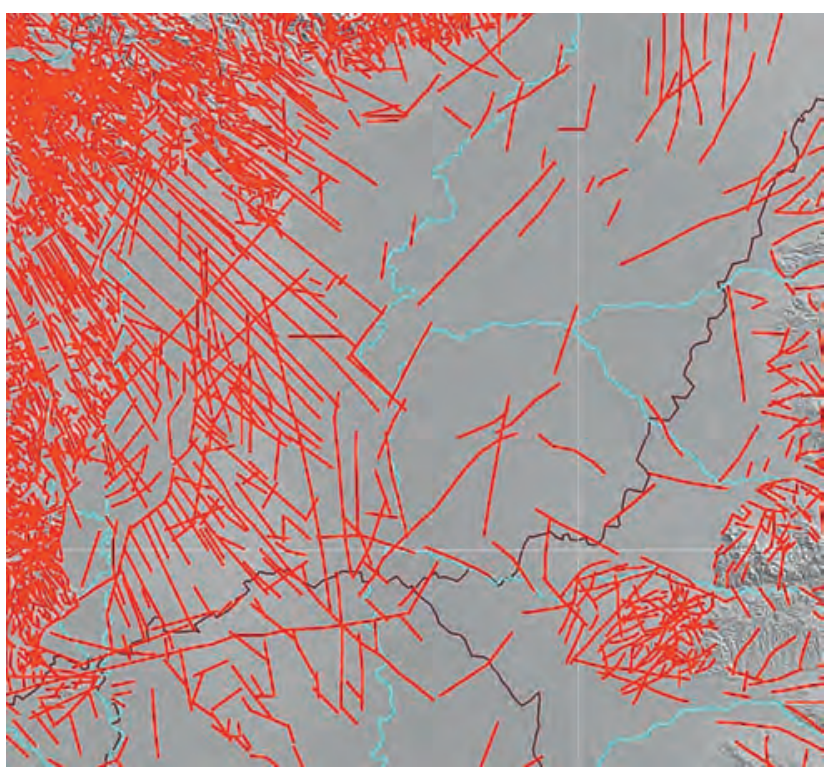

2. ábra A Pannon-medence és környezete morfostrukturális elemei (HoRvátH F. et al. 2006)

Figure 2 Morphostructural elements in the Pannonian Basin and environs (after HorvátH, F. et al. 2006) 
A Pannon-tenger, illetve -beltó feltöltődése során a paleozoós és mezozoós üledékekből álló medencealjzatra-eocén, oligocén üledékhézaggal-miocén és pliocén tengeri eredetû üledékek rakódtak. A hagyományos értelemben vett ,alsó pannóniai” formációkat az Endrődi Márga, a Szolnoki Homokkő és az Algyői Formáció, a „felső pannóniaiakat” az Újfalui Homokkő, a Zagyvai és a Nagyalföldi Tarkaagyag Formáció alkotja (JÁMBOR, Á. 1989). Nagy vastagságú beltengeri, tavi- és folyóvízi üledékek települtek a lesüllyedt felsőpannon medencealjzatra. A negyedidőszaki üledékek vastagsága 700-800 m. Többnyire folyóvízi üledékekből állnak, kisebb kiterjedésúek a tavi, mocsári és eolikus képződmények. A negyedidőszaki rétegsort többnyire homokos meder, övzátony, parti hát, illetve agyagos ártéri üledékek alkotják. Ezek fedőjében a halmokon eolikus lösz, a mélyedésekben tőzeges, tavi, mocsári üledékek-ártéri, vagy infúziós lösz-találhatók. Jelentős területet borítanak agyagos, löszös ártéri üledékek (RónAi A. 1972, 1985). DomoKos T. és KROLOPP E. (1997) szerint Mindszent környezete folyóvízi ártér volt a felső pleisztocénnek egy aránylag enyhe klímájú szakaszában. Kezdetben ártéri üledékek, majd a folyóvízi tevékenység fokozódásával folyóvízi üledékek rakódtak le.Az éghajlat kontinentálisabbá válásának hatására homokmozgás indult meg a száraz és csak gyér vegetációval fedett területen. A kis távolságról szállított homokhoz löszanyag is keveredett, majd a löszképződés került túlsúlyba. Ez a folyamat 18000-16000 éve ment végbe.

A folyóvízi felhalmozódások több alluviális szintet hoztak létre a Tisza árterén (GÁBRIS Gy.-NÁdor A. 2007; GÁBris, Gy. 2013). Kiss T. et al. (2013) és Hernesz P. et al. (2015) szerint az Alsó-Tisza mentén három ártérképződési és két bevágódási fázist lehet elkülöníteni, míg a Középső-Tisza mentéről négy szint ismert (KASSE, C. et al. 2010; GÁBRIS Gy. et al. 2012). A terepi megfigyelések szerint a Kurca bal partján két szint található (az alsó kb. 3 m-en, a magasabb kb. 4.5 m magasan a középvízszint felett (KIs É. et al. 2014). Az egyetlen megőrződött Tisza meander, a Kórógy-ér, kora 16.8 \pm 1.53 ka BP (KISS, T. et al. 2013a). A Maros medermaradványa a magas ártéren, a Kenyere-ér, $3.3 \pm 0.9$ és $10.8 \pm 0.99$ ka BP között keletkezett, míg a Téglás-ér az alacsony ártéren $12.21 \pm 1.53 \mathrm{ka}$ korú (Sipos, Gy. et al. 2009; Hernesz, P.-KISS, T. 2013). Az alacsony ártér tehát a pleisztocén végén, a holocén elején formálódott (KISs, T. et al. 2013b).

Mindkét szint gazdag mikroformákban: övzátonyok, folyóhátak, (időszakosan feltöltődő) elhagyott medrek, valamint antropogén pozitív és negatív formák (gátak, kubikgödrök stb.) tagolják a felszínüket. A lösszel borított magasabb felszínek réti és humuszos öntéstalajain szántóföldi múvelés folyik (Lóczy D. - KIs É. 1989), a hullámtér földhasználatát azonban szigorú jogszabályok korlátozzák.

\section{Módszer}

Két szélsőséges időjárású évben tanulmányoztuk a partfalmozgások okait, a folyópart tömegmozgásokra való hajlamát az Alsó-Tisza mentén. Ezek az évek a Tisza vízjárása tekintetében is szélsőségesnek számítottak. 2010 országosan messze a legnedvesebb év volt a meteorológiai megfigyelések kezdete óta, a sokéves átlagnál 30\%-kal több eső hullott. 2013 volt az az év, amikor a tél és a tavasz eleje igen csapadékos, a nyár viszont már aszályos volt. A 2013. évi legalacsonyabb vízállás - -22 cm - augusztus 26-án következett be.

Az alacsony vízállású időszakok a legalkalmasabbak a partfal-instabilitások elemzésére és a keletkezett formák dokumentálására, értelmezésére. A folyópart alakulásának átfogó vizsgálati programja keretében az Alsó-Tisza-meder 13 vizsgált szakaszán (lásd 1. ábra) végeztünk méréseket a más magyarországi folyókon is alkalmazott módszerekkel (BlanKa V. 2010). 
A felmérések közötti időre kiszámítottuk a parthátrálás mértékét és összevetettük a folyó vízjárásával, abból a célból, hogy megbecsülhessük, mekkora hatással voltak az egyes árhullámok és az ôket követô apadás a parterózió mértékére.

A terepi mérések alkalmával a partfejlődést leginkább meghatározó paramétereket (RosGen, D.L. 2001) felvételeztük. A kutatás során alkalmazott módszert az Amerikai Egyesült Államokban dolgozták ki, először alkalmaztuk Magyarországon hasonló földrajzi fekvésú környezetben. A nemzetközi szakirodalom szerint a parterózióban a legfontosabb szerepet játszó paraméterek (LAWLER, D.M. 1993; RosGEN, D.L. 2008; RATHBURN, B. 2012): a partmagasságnak és a nagyvízi meder mélységének a hányadosa, a parti növényzet gyökerezési mélysége és a partmagasság hányadosa, a gyökérzet súrúsége (ABERNETHY, B. 2000), a partfal lejtőszöge és a part védettsége. Ezekből a paraméterekből alakította ki Rosgen, D.L. (2001, 2008) a Parterózió Veszélyességi Indexet (Bank Erosion Hazard Index, BEHI) (lásd 3. ábra). A BEHI-I index vizsgálata folyamán a terepfelmérések során kapott fenti paraméterekből típusonkénti összpontszámot számoltunk, melyhez súlyozó tényezőként - eltérő pontszámérték kel - a part anyaga és rétegzettsége értékét is hozzászámoltuk. A kapott pontszámok alapján a partszakaszokat erózió veszélyük mértéke szerint 6 típusba - nagyon alacsony, alacsony, mérsékelt, nagyon magas és különösen magas soroltuk. A BEHI-II index számítása keretében nem számoltunk korábbi két tényezővel - a part magasságával és a nagyvízi mederrel -, paraméter volt a növényzet gyökerezési mélysége és sưrúsége, valamint a part védettsége és lejtőszöge. Súlyozó értékként szintén a part anyagát vettük figyelembe.

A BEHI index tehát a folyópart tömegmozgásokra való hajlamát mutatja meg. Ugyanakkor értékei összevethetôk a parti objektumok elhelyezkedésével. Az összehasonlításból pedig az is kiolvasható, hol van szükség feltétlenül partbiztosításra, illetve melyek azok a szakaszok, ahol a lassúbb partalakulás ökológiai szempontból hasznos lehet, emberi beavatkozást nem igényel.

Korábbi tiszai kutatásaink (KIs É. et al. 2014) tapasztalataira építve öt további paramétert is felvételeztünk és beépítettünk az indexbe: a partfal irányának a szerkezeti vonallal bezárt szöge, a növényzetborítás százalékos mértéke 10 m-es parti sávban, az üledéksorozatban az agyagos rétegek közé települt homokos üledékek aránya (lásd pl. THORNE, C.R.-Tovey, N.K. 1981), a helyi árvíz veszélyességi index (lásd LócZY D. et al. 2009) és a legnagyobb árvízi riasztás gyakorisága (NAGY L.-TAKÁcs A. 2013).

\section{Eredmények és értékelésük}

\section{A partfal alakulását befolyásoló tektonikai tényezók}

A süllyedő dél-alföldi területen az Alsó-Tisza morfológiáját alakító legfontosabb geológiai folyamat nyilvánvalóan a felszín fokozatos süllyedése (BADA G. et al. 2007). Az ennek következtében általánosan fellépő bevágódás miatt sorozatos partfalomlások következnek be. A folytonos süllyedés elsősorban DNy-ÉK irányú fó törésvonalak mentén megy végbe, amelyekhez a DK-ÉNy irányú vonalak mentén változó ütemű mozgások társulnak.

Konkrétan a Pannon-medence jelenlegi geodinamikájának atlasza térképlapjairól (HoRvÁTH F. et al. 2006), valamint BADA G. et al. (2007) összefoglaló munkájából a tanulmányozott területre a következő megállapításokat tehetjük.

Az általános tektonikai helyzet következtében partfalmozgások szükségszerúen előfordulnak, a jövőben is folytatódni fognak - minden egyéb hatástól függetlenül is (KIS É. et al. 2014). Véleményünk szerint ez a tektonikai helyzet az oka, hogy a részletes geo- 
morfológiai felvételezés és térképezés (KIS É.-LócZY D. 1985) csak kevés ártéri szintet tudott feltárni.

A folyómedernek a tektonikai vonalakkal bezárt szögét vizsgálva megállapítható, hogy a tanulmányozott folyószakaszok többsége vagy valamely tektonikai vonal mentén fut, vagy azzal $<10^{\circ}$-os szöget zár be. Négy olyan helyet mutattunk ki, ahol a két irány között jelentős az eltérés:

1. Az 1. a 2. és a 3. sz. partfal közelében egymással jelentős szöget bezáró két markáns törésvonal találkozik. Ennek következtében egy kb. 500 m hosszú kanyarulat keletkezett, amelyet markáns csuszamlások sorozata formál.

2. A mindszenti nagyrév körzetében a magas ártér pereme É-D-i irányú törésvonalat követ. Ezzel csaknem derékszöget $\left(86^{\circ}\right)$ szöget zár be az a törésvonal, amely mentén a Dong-ér alakult ki.

3. A csanyteleki partomlásos sáv a mintegy 50 m átmérójü nagy kanyar (a korábbi hajókikötő) meredek eróziós partjait foglalja el. E partfalak mentén fordul D felé az ÉK-DNy-i törésvonal. Ezekre a partfalakra ismét csaknem merőlegesen futnak ki a csuszamlásos falaktól D-re és É-ra az ÉNy-DK-i irányú markáns törésvonalak.

4. Végül jelentős a Körös-törésvonal hatása a Körös-torok környéki partfalakra. A 8., a 11., a 12. és a 13. sz. partfalak az É-D-i irányú fő törésvonallal is szöget zárnak be. Ugyanúgy kimutatható az ÉNy-DK-i lineamensek befolyása is.

\section{A partszakaszt felépitő közetek minösége és rétegzettsége}

A vizsgált partfalak agyagrétegei laza löszös, iszapos, homokos üledékek váltakoznak. Az agyagos ártéri lösznek különleges jelentősége van a mozgások keletkezésében. Ugyanazon árvízi időszakban a lazább szerkezetű löszben korábban következik be a csuszamlás, mint pl. a Duna-menti tömörödöttebb, homokos löszfalak esetében (KASZÁs F.-TAKÁCS A. 2013). Alapvető különbség az egyes partfalak között a különféle löszváltozatok megjelenése és aránya. Ezek a változatok lazább vagy tömörebb szerkezetúek. A dunai partfalak típusos, míg a tiszai partfalak ártéri (,infúziós”) löszből állnak. Az ártéri lösz fizikai sajátosságai jelentősen eltérnek a típusos lösz jellemző tulajdonságaitól, ezért inkább csak löszszerú üledékeknek tekinthetők. A partfalat felépítő üledékek százalékos agyag-, iszap-, lösz és homoktartalmának összevetése magyarázatot ad a partfalak csuszamlás veszélyessége közötti különbségekre.

A legfontosabb tényező az agyagtartalom, illetve az agyagásványok minőségi összetétele. Az ártéri viszonyok között képződött löszök lényegesen agyagosabbak. Amikor a folyó vízállása az árvízi vízállásgörbe leszálló ágában hirtelen csökken, a nagy agyagtartalom

3. ábra A BEHI parteróziós index paraméterei (RosGEN, D.L. 2008). A, a partfal magassága; B, vízmélység a parton mederkitöltő vízhozamkor; $\mathrm{C}$, a gyökérzet sűrûsége; D, a növényzet gyökerezési mélysége; I, a part védettsége; $\mathrm{H}$, a part lejtőszöge

Figure 3 Parameters of the Bank Erosion Hazard Index (RosGen, D.L. 2008): A, bank height; B, water depth at bank during bankfull discharge; $\mathrm{C}$, root density; $\mathrm{D}$, rooting depth of vegetation; I, surface protection; $\mathrm{H}$, bank angle

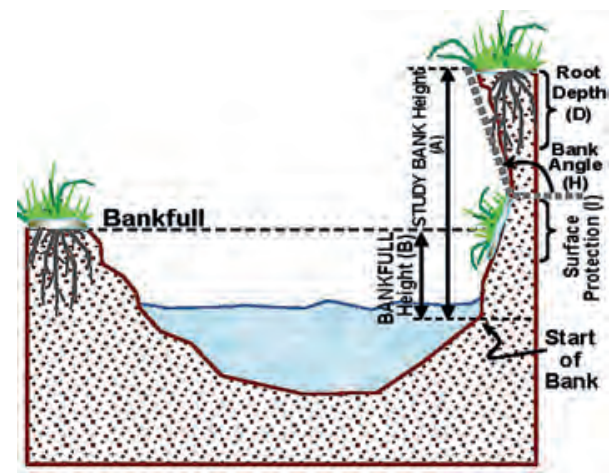


miatt az ártéri löszös partfalban lévő víz sokkal nehezebben tud visszajutni a folyóba. A sokkal lazább, lényegesen típusos löszpartfalakban nagyobb a homoktartalom, ezért az adott esetben könnyebben megy végbe a vízmozgás. A 2013. évi árvíz idején történt sorozatos Alsó- és Közép-Tisza menti partfalcsúszások egyértelmúen a Tisza vízszintingadozásához köthetők, de antropogén tényezők, zsilipek és tározók építése is kimutathatók bennük. Ugyanakkor a Duna mentén bekövetkezett jelentős felszínmozgásokat a szakértők vizsgálatai (pl. a kulcsi domboldal vagy a dunaszekcsői Várhegy omlásait - BUGYA, T. et al. 2011; NAGY L. - TAKÁCS A. 2013; KASZÁs F. - TAKÁCS A. 2013; TAKÁCS A. - KASZÁs F. 2013) nem kapcsolták össze közvetlenül a Duna vízszintingadozásaival. A Budapesti Műszaki Egyetem Általános és Felsőgeodéziai Tanszékének munkatársai azt állapították meg, hogy a felszínmozgásoknál a felülről érkezó és a parti sávban áramló vizeknek lényegesen nagyobb befolyásuk van, mint a folyó hirtelen apadásából származó hatásnak. A 2013. évi dunai árhullám a dunaszekcsői magasparttal együtt a kulcsit is érintette. Az utóbbi település fokozott mértékben ellenőrzött négy felszínmozgásos partszakaszán is azt tapasztalták, hogy az áradó, majd apadó víz közvetlenül nem váltott ki mozgást. Geomorfológiai szempontból a vizsgált partfalcsúszások jelentős része a magas és az alacsony ártér peremként kirajzolódó határvonalán (a mindszenti Tisza-szakaszon a kompátkelőnél és az ányási saroknál) jön létre (1. kép). Megfigyelhető, hogy a mozgások elsősorban a mára feltöltődött egykori meanderek hordalékanyagát érintik, az mozdul el a folyómeder irányában.

Kőzetminőség és -szerkezeti probléma, hogy a mozgások csúszólap mentén zajlanak-e le, vagy a nyírófeszültség nagyjából egyenletesen oszlik el a parti sáv kőzettömegében.

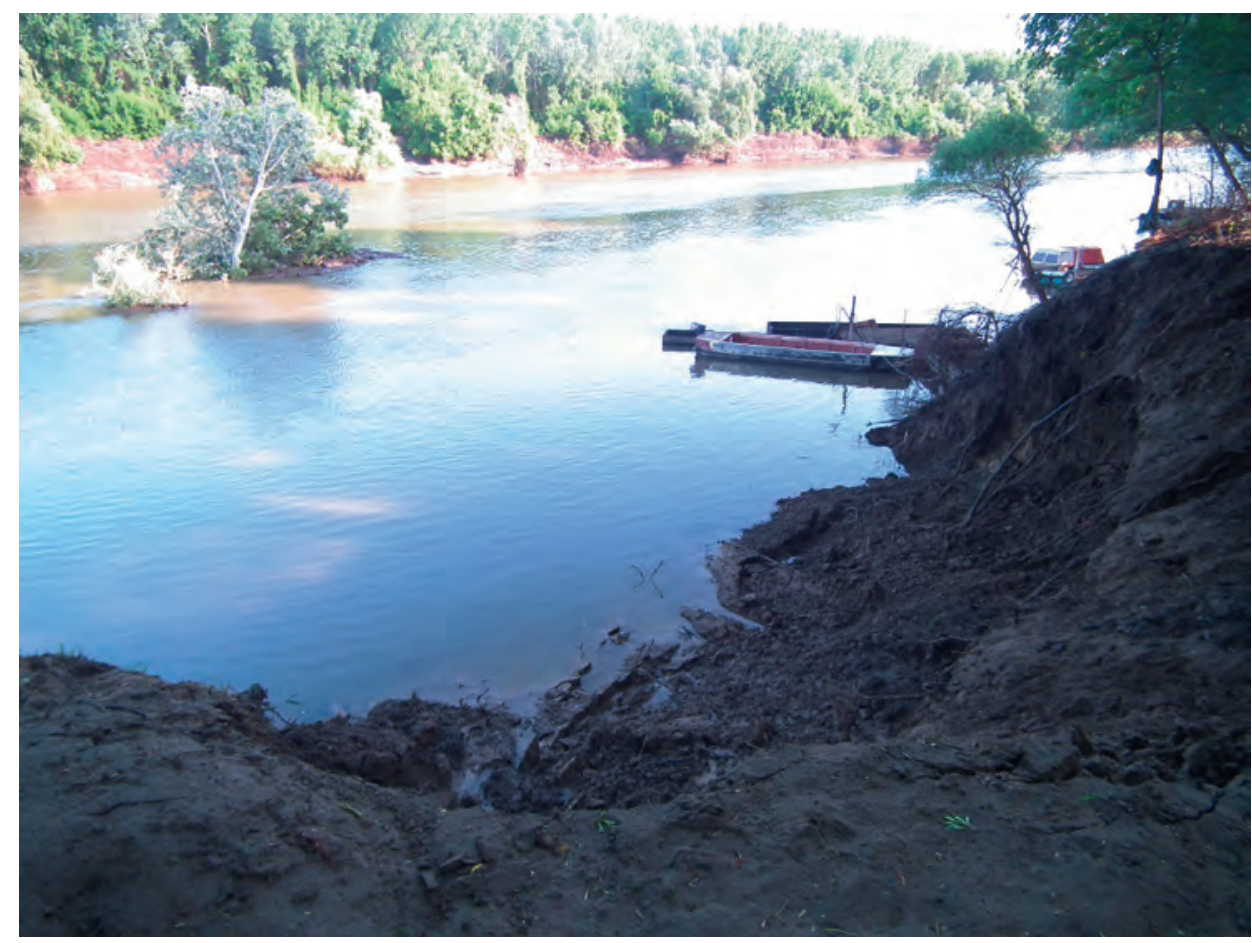

1. kép Karéjos csuszamlás a mindszenti Nagyrév É- i részén (Fotó: Kis MoLNÁR I.) Picture 1 Arcuate landslide $\mathrm{N}$ of the Mindszent Nagyrév (Photo by Kis MoLnáR, I.) 
A tiszai ártér löszös üledékei alatt a vizsgált területen mindenütt megtalálhatók a kékagyag-szintek, amelyek egykori tavi, mocsári üledékképződési környezeteket jeleznek. Ezek rétegei enyhén dőlnek a folyó felé (2. kép). A talajvíztükör a csuszamlások teljes időtartama alatt lejtett a folyó felé. Tapasztalható volt, hogy a csúszással kimozdított tömbökből még két hét múlva is csöpögött a víz. A csúszópályák menti elmozdulás tehát terepi megfigyeléssel is jól bizonyítható volt.

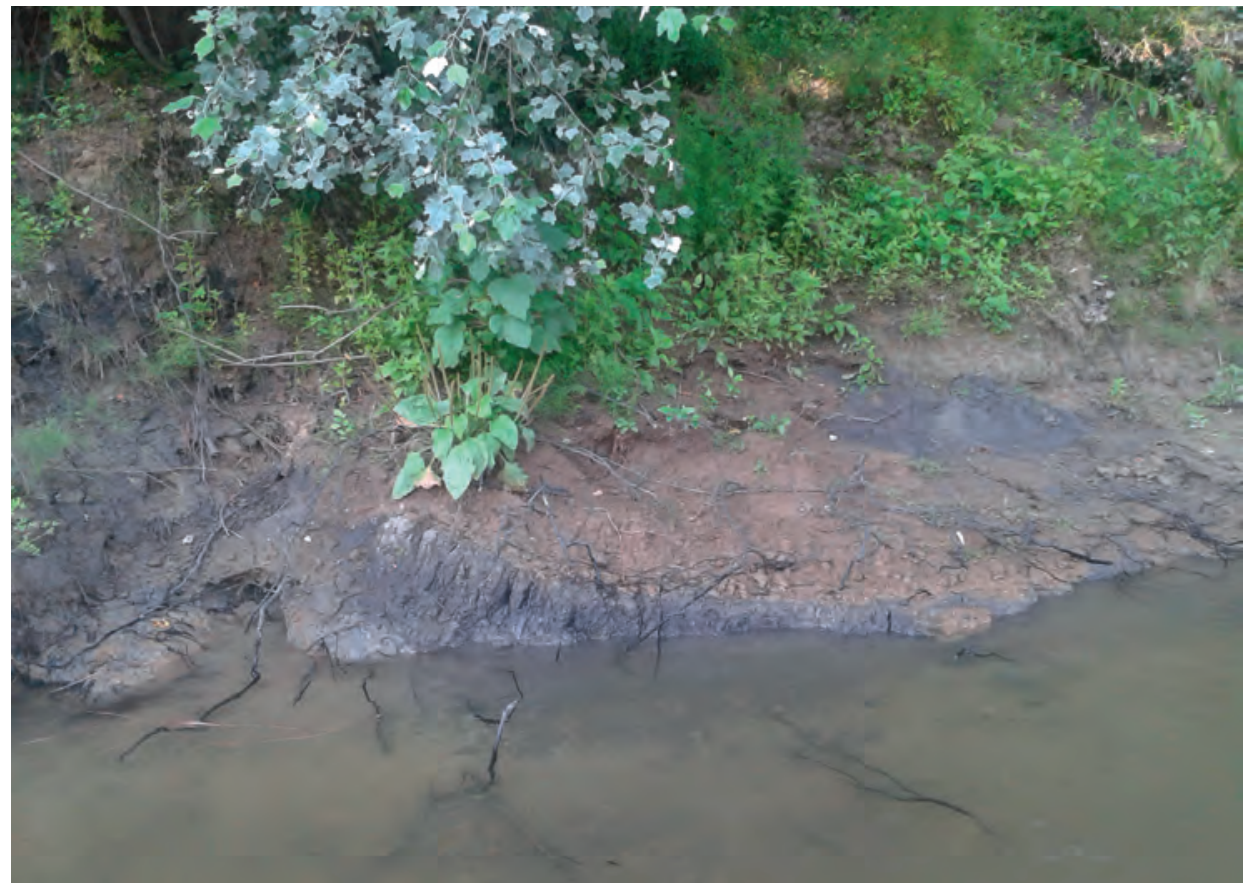

2. kép A folyóvízi üledékek alatti kékagyag a fluviális üledékképződés előtti tavi és mocsári környezetet jelöl (Fotó: Kis É.)

Picture 2 Blue clays under fluvial deposits indicate lacustrine and paludal sedimentation environments (Photo by Kis, É.)

Kőzetszerkezeti szempontból módosította meg a mozgások végbemenetelét a part anyagának repedezettsége (3. kép). Ennek a hatásnak a mértékét a repedések sűrüségével, irányultságával, szélességével és kitöltésük anyagi minóségével igyekeztük jellemezni (KIS É. et al. 2014).

\section{Idójárási viszonyok, a rétegek átnedvesedése}

A mozgások közvetlen kiváltó okai között természetesen nagy jelentősége lehet az időjárási (elsôsorban csapadék-) viszonyoknak. A 2013. év első három hónapjában a sokévi átlagos csapadékmennyiség kétszerese hullott le. A csúszást megelőző hónapban (mindöszsze négy nap kivételével) minden nap hullott áztató eső. A csúszópályákat alkotó rétegek víztartalma és a víznyomás tehát gyorsan növekedett. Emellett annak is lehet jelentôsége, hogy a viharos időszakokban nagyobb erejű széllökések is előfordultak és velük párhuzamosan repedések kialakulását, tágulását lehetett észlelni (a mindszenti kompátkeló és a Köröstoroki-zsilip között). 


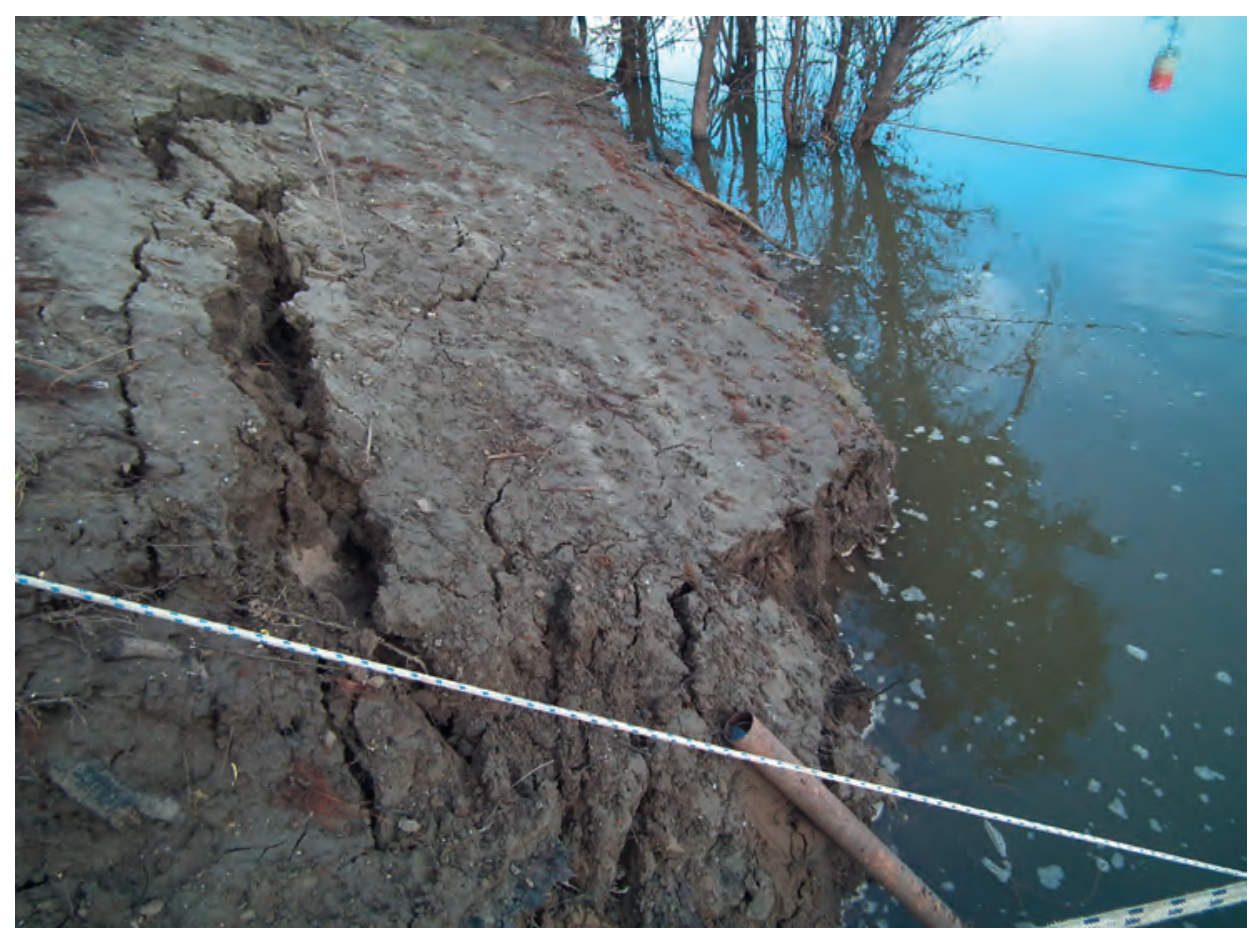

3. kép Közvetlen csuszamlás előtti időszak kinyíló karéjos repedésekkel és a kőzetrepedésekből kihabzó vízzel (Fotó: Kis MOLNÁR, I.)

Picture 3 Arcuate fractures and foam from cracks immediately before the landslide is triggered

(Photo by I. KIS MOLNÁR)

Az aszályos időszakokat követő csapadékos években (pl. 2010-ben és 2013-ban) bekövetkező nagy tavaszi árvizek után a Közép-és a Dél-Tisza mentén sorozatos partfalcsúszások léptek fel. Ugyanezen időszakokban és nagyon hasonló időjárási körülmények között a dunai partfalak mentén azonban nem keletkeztek sorozatos omlások és csuszamlások. A helyi üledéksorozat jellege tehát közvetlenül befolyásolja azt, hogy az időjárási jelenségek milyen mértékben képesek kiváltani felszínmozgásokat a partok mentén.

A nagyobb árvizek és a nyári felhőszakadások következményeként fellépő átnedvesedés bizonyos esetekben gyors mederalakuláshoz vezetett. Jelentős mértékben magasodtak pl. az övzátonyok a hosszan tartó, több hetes árvízi elöntés alatt. A vizsgált két árvizes évben, 2010-ben és 2013-ban árvízkor bizonyos szakaszokon összesen 2 m-t elérő felhalmozódást is tapasztaltunk. 2013-ban a Tisza vízszintjének májusi lassú emelkedését gyors apadás, az évtized leggyorsabb vízszintcsökkenése követte (6 m csökkenés 8 nap alatt). A hirtelen jelentős vízszintesésben antropogén tényezők is szerepet játszhattak (víztározók, zsilipek, stb. hatása). A vízszintcsökkenés hatására a partszakasz elveszítette állékonyságát. A partot felépítő laza szerkezetű ártéri löszös üledékben ún. „vízgazdálkodási zavar” jött létre. Ilyen helyzetben a parton lévő fák is számottevő mértékben csökkentették a partfal állékonyságát. A parti fák egyre terjedelmesebb gyökérzetet fejlesztenek, megnövelik a nyírófeszültséget, nagy mértékben, de esetenként különböző irányban befolyásolják, elősegítik vagy éppen akadályozzák a partok pusztulását (4. kép) (BENNETT, S.J. -SimON, A. 2004). Hirtelen apadáskor a partról az üledékrétegek a bennük gyökerező fákkal együtt csúsztak a Tiszába. Néhány napig vagy egy-két hétig fennmaradó mederközépi zátonyok keletkeznek. 


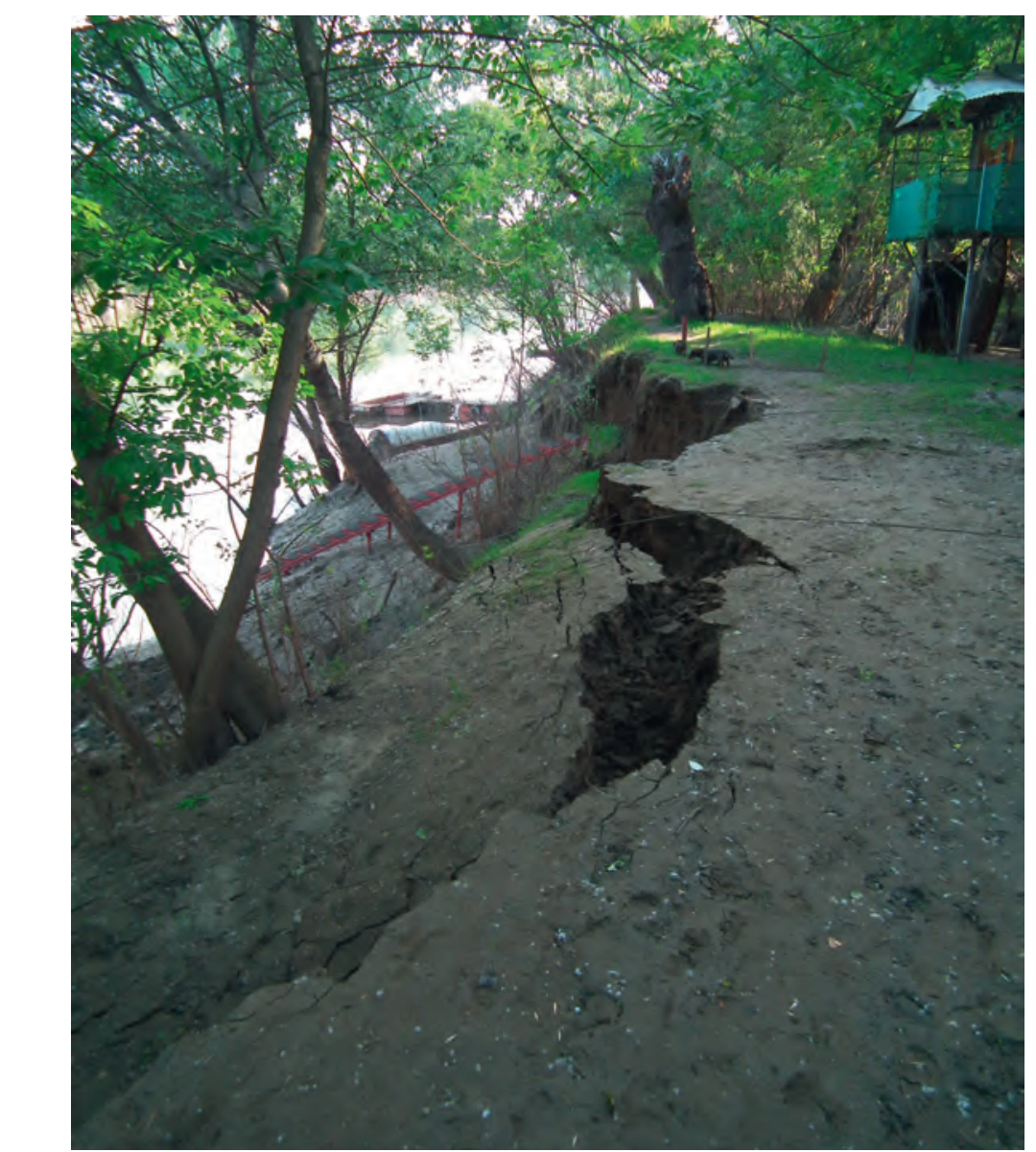

4. kép A partszakasszal párhuzamos, a növények gyökerei mentén előrejelzett repedések (Fotó: KIS MoLNÁR I.) Picture 4 Cracks parallel with the bank preformed by tree roots (Photo by KIS MoLNÁr, I.)

\section{Antropogén befolyásolás: a folyószabályozás utóhatásai}

A 19. századi szabályozások során a Tisza túlfejlett kanyarulatait levágták, kétszeresére növelve a folyó esését, a parterózió sebességét, így a csuszamlások kialakulására akaratlanul is kedvező körülményeket teremtettek. A tanulmányozott szakasznak majdnem felén épültek partbiztosítási múvek a 19. század elejétől fogva (5. kép). Ezek egy-egy kanyarulat külső ívén erősítették meg a partfalat, azonban hatnak az alattuk lévő kanyarulatokra is. Megépítésükkel ezek a mútárgyak lecsökkentették a mederszelvények szélességét, a Tisza medrének vízelvezető képességét. Mindennek következményeképpen a levonuló árvizek szintje emelkedett (FIALA K. et al. 2006). A bevágódó mederben a kisvizek szintje viszont csökkent, így apadáskor fokozódó vízszintingadozások léptek fel. A folyószabályozás miatt tehát hosszú távon növekedett a csuszamlások kialakulásának valószínúsége is.

Vizsgálataink során igyekeztünk a szerint is különbséget tenni a partfalak között, hogy azok a Tisza szabályozás előtti vagy szabályozás utáni medrének mentén alakultak-e ki. A szabályozás utáni új medrekben a megnövekedett esés és a bevágódás miatt jelentős 


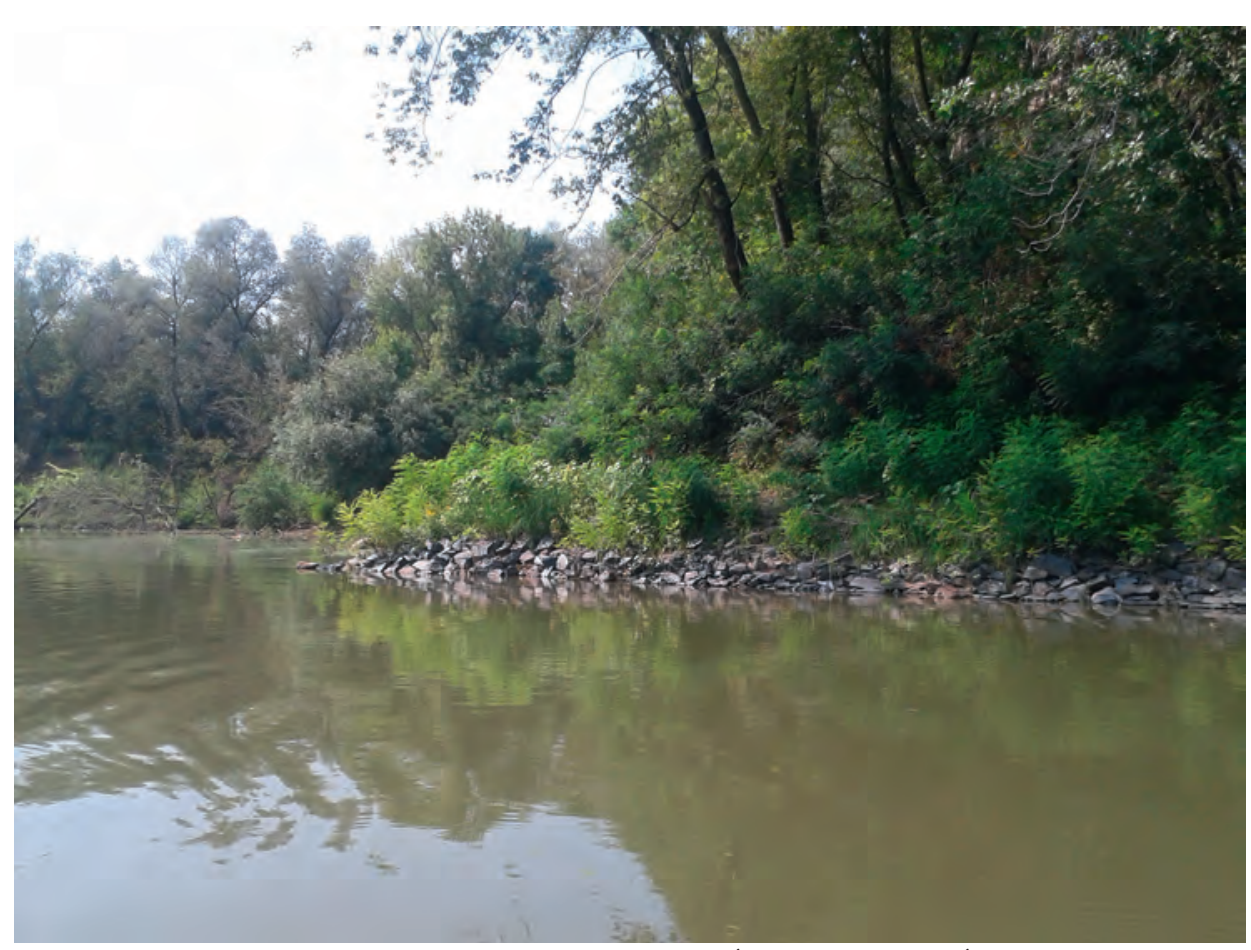

5. kép Partbiztosítás a csanyteleki kanyarulat ÉK-i részén (Fotó: KIs É.)

Picture 5 Bank enforcement in the NE of the Csanytelek meander (Photo by KIS, É.)

mértékű lehet a partpusztulás. (A vizsgált partszakaszok közül a 13. sz. tartozik új Tiszamederhez, a csongrádi hídtól É-ra, a csongrádi Holt-Tiszával szemben).

\section{A partpusztulás mértékének meghatározása}

A parteróziós index adaptálásával kapott eredmények alapján megállapíthatjuk, hogy a módszer magyarországi alkalmazása sikeres volt, a fent említett célkitűzések megvalósultak. A módszert USA-beli kis- és közepes, hasonló földrajzi fekvésú folyók partpusztulás mértéke jellemzésére vezették be. Az alkalmazott BEHI-I és BEHI-II indexek paraméterértékei közül a BEHI-I indexben alkalmazott nagyvízi meder paraméter-értékei nem mutattak lényeges változást, értéke szinte minden esetben 1,0 és 1,1 között ingadozott (6. kép, 1. táblázat). Ez azt jelenti, hogy a vízmélységnek egy már kb. 10 m nagyvízi meder mélységú folyó esetében nincs hatása a partpusztulás mértékére. Tehát nincs szükség ennek az indexnek az alkalmazására.

A kutatás egyik fő eredményének tartjuk a 13 vizsgált partszakasz BEHI-I és BEHI-II értékeinek összehasonlítását (2. táblázat), melynek során 6 BEHI típust alakítottunk ki. Az adott partszakasz különbözó besorolásának tisztázása céljából vizsgáltunk még másik fent részletezett 5 módosító paraméter-értéket is. A geomorfológiai viszonyok értékelése eredményre vezetett. A geomorfológiai térképeken az alacsony és a magas ártér, valamint az ártéri sziget határainál bejelölhető várható csuszamlási helyek többnyire megegyeznek a magas és nagyon magas BEHI típusú partfalszakaszokkal. Ezeken a helyszíneken mindenképpen javasolható a partbiztosítás megerősítése. 


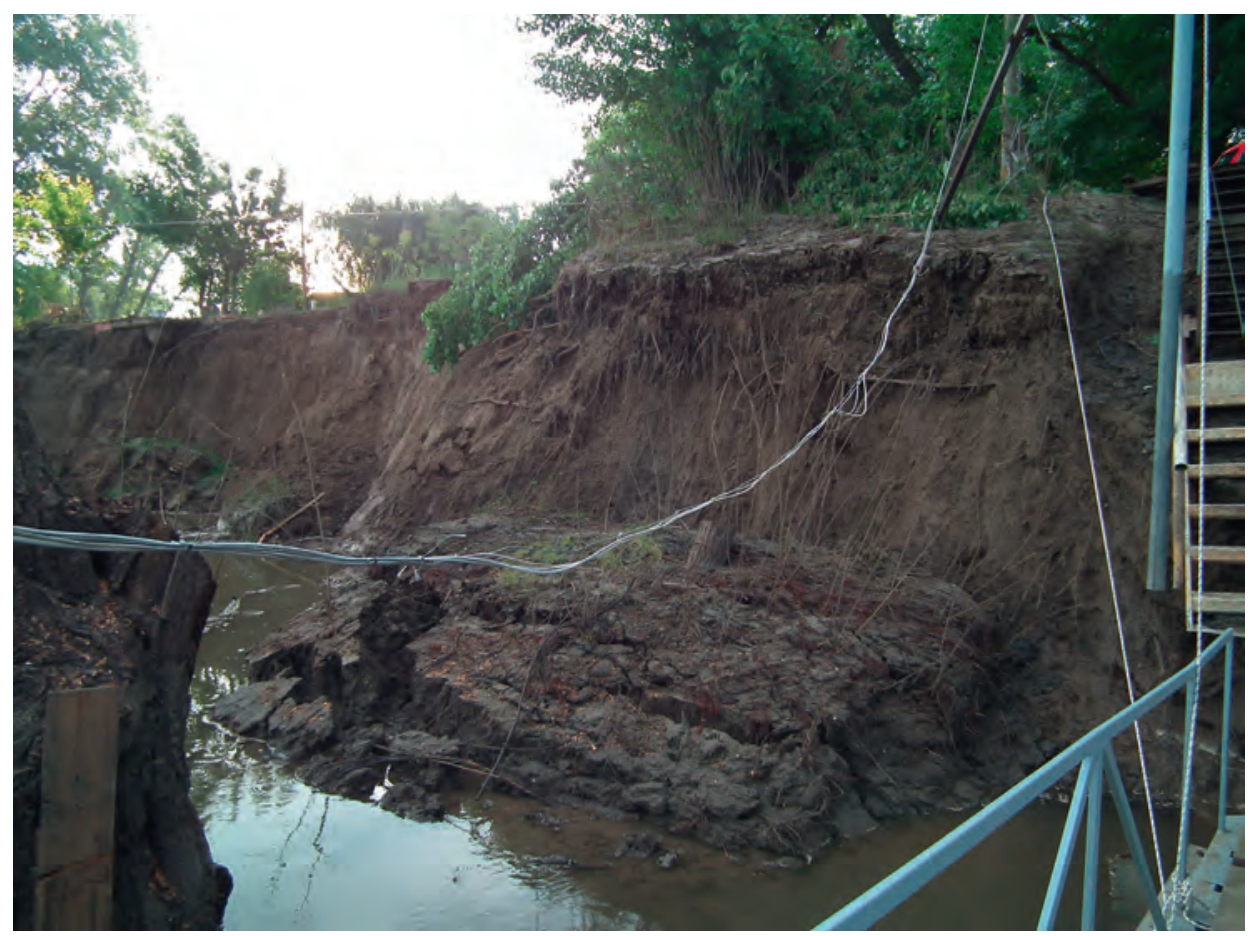

6. kép Csuszamlásos partfal (2013) a mindszenti Halászcsárda mellett (Fotó: Kis MoLNÁR I.) Jellemző BEHI-I értékek: A part magassága/nagyvízi meder mélysége $\approx 1,0-1,1$; A parti növényzet gyökerezési mélysége /a part magassága: $0,29-0,15$; A gyökérzet sűrűsége $\approx 29$-15; A partfal lejtőszöge $\approx 61-80$; A part védettsége $\approx 100-80$; Összesen $=17-22,6 ;$ A part anyaga $\approx 5$ (löszös anyag); Rétegezettség $\approx 10 ;$ BEHI pont $=42,5$ (nagyon magas)

Picture 6 Bank with landslide next to the Fish Restaurant of Mindszent in 2013 (Photo by KIs MolnáR, I.)

1. táblázat-Table 1

Módosított Parterózió Veszély Index BEHI-II értékek a mindszenti Halászcsárdánál

Modified Bank Erosion Hazard Index, BEHI-II values at the Fish Restaurant of Mindszent

\begin{tabular}{|c|c|c|c|c|c|c|c|c|c|}
\hline \multirow{3}{*}{$\begin{array}{l}\text { BEHI } \\
\text { típusok }\end{array}$} & \multicolumn{4}{|c|}{ Növényzet } & \multicolumn{4}{|c|}{ Part } & \multirow{3}{*}{$\begin{array}{l}\text { Összpont- } \\
\text { szám } \\
\text { típusonként }\end{array}$} \\
\hline & \multirow{2}{*}{\multicolumn{2}{|c|}{$\begin{array}{l}\text { gyökerezési } \\
\text { mélység } \\
\text { mélység pont- } \\
\text { értéke szám }\end{array}$}} & \multicolumn{2}{|c|}{ sűrûsége } & \multicolumn{2}{|c|}{ védettség } & \multicolumn{2}{|c|}{ lejtőszög } & \\
\hline & & & $(\%)$ & $\begin{array}{l}\text { pont- } \\
\text { szám }\end{array}$ & $(\%)$ & $\begin{array}{l}\text { pont- } \\
\text { szám }\end{array}$ & $\left(^{\circ}\right)$ & $\begin{array}{l}\text { pont- } \\
\text { szám }\end{array}$ & \\
\hline $\begin{array}{l}\text { Nagyon } \\
\text { alacsony }\end{array}$ & $90-100$ & 1.45 & $80-100$ & 1.45 & $80-100$ & 1.45 & $0-20$ & 1.45 & $\leq 5.8$ \\
\hline Alacsony & $50-89$ & 2.95 & 55 & 2.95 & 9 & 2.95 & $1-60$ & 2.95 & $5.8-11.8$ \\
\hline Mérsékelt & $30-49$ & 4.95 & $30-54$ & 4.95 & $30-54$ & 4.95 & $61-80$ & 4.95 & $11.9-19.8$ \\
\hline Magas & $15-29$ & 6.95 & $15-29$ & 6.95 & $15-29$ & 6.95 & $81-90$ & 6.95 & $19.9-27.8$ \\
\hline $\begin{array}{l}\text { Nagyon } \\
\text { magas }\end{array}$ & $5-14$ & 8.5 & $5-14$ & 8.5 & $10-14$ & 8.5 & $91-119$ & 8.5 & $27.9-34.0$ \\
\hline $\begin{array}{l}\text { Különösen } \\
\text { magas }\end{array}$ & $<5$ & 10 & $<5$ & 10 & $<10$ & 10 & $>119$ & 10 & $34.1-40$ \\
\hline
\end{tabular}


2. táblázat - Table 2

A BEHI-I és BEHI-II értékek összehasonlítása a tanulmányozott 13 partszakaszra

Comparison of BEHI-I and BEHI-II values for the 13 bank sections studied

\begin{tabular}{lccccccccccccc}
\hline $\begin{array}{l}\text { Part- } \\
\text { szakasz }\end{array}$ & 1. & 2. & 3. & 4. & 5. & 6. & 7. & 8. & 9. & 10. & 11. & 12. & 13. \\
\hline $\begin{array}{l}\text { BEHI I. } \\
\text { érték }\end{array}$ & 34,5 & 39,6 & 37,5 & 36,5 & 32,5 & 42,5 & 44,5 & 36,5 & 36,5 & 37,5 & 17,5 & 33,5 & 34,5 \\
$\begin{array}{l}\text { BEHI II. } \\
\text { érték }\end{array}$ & 26,8 & 34,8 & 34,8 & 34,8 & 34,7 & 34,8 & 26,8 & 34,8 & 35,5 & 34,0 & 16,8 & 34,8 & 26,8 \\
\hline
\end{tabular}

Jelkulcs:

Nagyon alacsony

Magas

Alacsony
Nagyon magas

Mérsékelt

Különösen magas

\section{Következtetések}

A parterózió legdinamikusabb hajtóerejeként a folyó vízjárásának ingadozásai jelölhetők meg, amelyeket erősen befolyásolnak az időjárási szélsőségek (egyebek mellett az egy éven belül váltakozó nedves és aszályos periódusok) is. Mivel a globális éghajlatváltozás hatására a hidrometeorológiai szélsőségek a jövőben várhatóan felerősödnek, ezért a parterózió az egyes szakaszokon egyre súlyosabb veszélyforrássá válik. A folyópart mentén bekövetkező tömegmozgások gyakorisága és intenzitása fokozódik, a geomorfológiai, földtani (tektonikai és üledékföldtani), valamint hidrológiai szempontból erre legkedvezőbb helyeken, szakaszokon. A BEHI index segítségével meg lehet határozni a folyószabályozás (kanyarulat levágások) által leginkább érintett helyszíneket, ahol az emberi társadalom tevékenysége, a korábbi beavatkozások utóhatásai a természetes tényezőkkel legalább azonos mértékú hajtóerők. A kutatás elősegíti ezeknek a kritikus szakaszoknak az azonosítását, a védekezés térbeli optimalizálása érdekében.

\section{Köszönetnyilvánítás}

A kutatást a 20765/3/2018 FEKUTSTRAT „Felsőoktatási Intézményi Kiválósági Program” címú projekt 3/1. tématerülete („Innovációval a fenntartható, egészséges életért és környezetért") támogatta.

KIS ÉvA

MTA CSFK Földrajztudományi Intézet, Budapest

kis.eva@csfk.mta.hu

LÓCZY DÉNES

PTE TTK Természet- és Környezetföldrajzi Tanszék, Pécs

loczyd@gamma.ttk.pte.hu 


\section{IRODALOM}

Abernethy, B. 2000: The effect of riparian tree roots on the mass-stability of riverbanks. - Earth Surface Processes and Landforms 25. 921-937.

BadA, G.-Horváth, F.-Dövényi, P.-SzAfián, P.-Windhoffer, G.-Cloetingh, S. 2007: Present-day stress field and tectonic inversion in the Pannonian basin. - Global and Planetary Change 58. 1-4. pp. 165-180 doi: 10.1016 /j. gloplacha. 2007.01.007

Benda, L.-Poff, N.L.-Miller, D.-Dunne, T.-Reeves, G.-Pess, G.-Pollock, M. 2004: The network dynamics hypothesis: How channel networks structure riverine habitats. - BioScience 54. 413-427.

Bennett, S.J.-Simon, A. (eds) 2004: Riparian Vegetation and Fluvial Geomorphology. - American Geophysical Union, Washington, DC. 283 p. (Water science and application 8)

BLANKA V. 2010: Kanyarulatfejlődés dinamikájának vizsgálata természeti és antropogén hatások tükrében. - PhD értekezés, Szegedi Tudományegyetem, Szeged. 145 p.

BlankA, V.-KISS, T. 2011: Effect of different water stages on bank erosion, case study on River Hernád, Hungary. - Carpathian Journal of Earth and Environmental Sciences 6. 2. 101-108.

Bravard, J.P.-Gilvear, D. 1996: Hydrological and geomorphological structure of hydrosystems. - In: PETTS, G.E.-Amoros, C. (eds.): Fluvial Hydrosystems. Chapman and Hall, London. 98-116.

BugYa, T.-FÁBIÁN, Sz.Á.-GöRCs, N.-KovÁcs, I.P.-RADVÁnSZKY, B. 2011: Surface changes on a landslide affected high bluff in Dunaszekcső (Hungary). - Open Geosciences 3. 2. pp. 119-128. doi: 10.2478/s13533011-0014-6

Buijse, A.D.-Coops, H.-Staras, M.-Jans, L.H.-VAn Geest, G.J.-Grifts, R.E.-Ibelings, B.W.-OosterberG, W.-Roozen, F.C.J.M. 2002: Restoration strategies for river floodplains along large lowland rivers in Europe. - Freshwater Biology 47. 889-907.

CAsagli, N.-Rinaldi, M.-Gargini, A.-CuRini, A. 1999: Pore water pressure and stream bank stability: Results from a monitoring site on the Sieve River, Italy. - Earth Surface Processes and Landforms 24. 1095-1114.

Chin, A.-Gregory, K.J. 2005: Managing urban river channel adjustments. - Geomorphology 69. $28-45$.

Church, M. 2000: Geomorphic thresholds in riverine landscapes. - Freshwater Biology 47. 541-557.

COUPER, P.R. 2004: Space and time in river bank erosion research: A review. - Area 36. 387-403.

DomoKos T.-KrolopP E. 1997: A Mindszent melletti Koszorúhalom és Szöllő-part negyedidőszaki képződményei és Mollusca-faunájuk. - Folia Historico-Naturalia Musei Matraensis 22. 25-41.

EPA 2007: National Management Measures to Control Nonpoint Source Pollution from Hydromodification. - Environmental Protection Agency, Washington, D.C. www.epa.gov/owow/nps/hydromod/index.htm

Fiala K.-Sipos Gy.-Kiss T. 2006: Szabályozások hatására bekövetkező morfológiai változások a Tisza és a Maros alsó szakaszán. - In: KISs A.-MEzősi G.-SüMEGHY Z. (szerk.): Táj, környezet és társadalom. Szegedi Tudományegyetem, Szeged. pp. 203-211.

Florsheim, J.L.-Mount, J.F.-Chin, A. 2008: Bank Erosion as a Desirable Attribute of Rivers. - BioScience 58. 6. 519-529. doi:10.1641/B580608

GÁBRIS GY. 2013: A folyóvízi teraszok hazai kutatásának rövid áttekintése - a teraszok kialakulásának és korbeosztásának új magyarázata. - Földrajzi Közlemények 137. 240-247.

GÁbris, Gy.-HorvÁth, E.-Novothny, Á.-RusZKicZAY-RÜDiger, Zs. 2012: Fluvial and aeolian landscape evolution in Hungary - results of the last 20 years research. - Geologie en Mijnbouw - Netherlands Journal of Geosciences 91. 1-2. 111-128.

GÁBRIS GY.-NÁDOR A. 2007: Long-term fluvial archives in Hungary: response of the Danube and Tisza rivers to tectonic movements and climatic changes during the Quaternary: a review and new synthesis. - Quaternary Science Reviews 26. 2758-2782.

GILVEAR, D.J. 2000: Fluvial geomorphology and river engineering: Future roles utilizing a fluvial hydrosystems framework. - Geomorphology 31. 229-245.

Gregory, S.V.-Swanson, F.J.-Mckee, A.-Cummins, K.W. 1991: An ecosystem perspective of riparian zones. - BioScience 41. 540-551.

HaAs, J. (ed.) 2013: The Geology of Hungary. - Springer, Heidelberg - Berlin. 244 p.

HASEGAWA, K. 1989: Studies on qualitative and quantitative prediction of meander channel shift. IKEDA, S.-PARKER, G. (eds.): River Meandering (Water Resources Monograph). - American Geophysical Union, Washington, D.C. pp. 215-235.

Hernesz P. 2015: Késő-pleisztocén és holocén ártérfejlődés az Alsó-Tisza mentén. - PhD értekezés, Szegedi Tudományegyetem. $128 \mathrm{p}$.

Hernesz P.-Kiss T.-SipOs Gy. 2015: Ártéri szintek és paleo-medrek: ártérfejlődés az Alsó-Tisza mentén. - Földtani Közlöny 145. 3. 273-286.

HooKe, J.M. 1979: An analysis of the processes of river bank erosion. - Journal of Hydrology 42.1-2. 39-62. 
Horváth F.-BAda G.-Windhoffer G.-CSOntos L.-Dombrádi E.-Dövényi P.-Fodor L.-Grenerczy G.-Síkhegyi F.-Szafián P.-SzéKely B.-Timár G.-Tóth L.-Tóth T. 2006: A Pannon-medence jelenkori geodinamikájának atlasza: Euro-konform térképsorozat és magyarázó. http://geophysics.elte.hu/atlas/09.htm

Horváth, F.-Cloetingh, S. 1996: Stress-induced late-stage subsidence anomalies in the Pannonian Basin. - Tectonophysics 266. 1. 287-300. doi: 10.1016/S0040-1951(96)00194-1

JÁMBOR, A. 1989: Review of the geology of the s.1. Pannonian formations of Hungary. - Acta Geologica Hungarica 32. 269-324.

Joó, I. 1996: Vertical movements of the Earth's surface in Hungary. - Geodézia és Kartográfia 48. 4. 6-12.

KASSE, C.-Bohncke, S.J.P.-VANDEnBerghe, J.-GÁBRIS, Gy. 2010: Fluvial style changes during the last glacial-interglacial transition in the Middle Tisza valley (Hungary). Proceedings of the Geological Association 121. 2. 180-194.

KASZÁs F.-TAKÁCs A. 2013: Kulcs és Dunaszekcső csuszamlásveszélyes területeinek mozgása a 2013.évi dunai árhullám idején. - In: TÖRÖK Á.-GöRÖG P.-VÁsÁRHELYI B. (szerk.): Mérnökgeológia-Kőzetmechanika 2013. 366 p.

Kis É.-BAlogh J.-SzeberénYi J.-Viczián I.-ProdÁn T.-Ő́rsi A. 2014: Felszínmozgási folyamatok vizsgálata a Tisza Mindszent környéki partfal szakaszain. - In: KóRódi T.-SANSUmné MolnÁR J.-SiskánÉ SzILAsi B.-Dobos E. (szerk.): A VII. Magyar Földrajzi Konferencia Kiadványa, Miskolci Egyetem, Földrajz - Geoinformatikai Intézet, Miskolc. 283-297.

KIs É.-LóCZY D. 1985: Geomorfológiai térképezés környzetminősítési céllal. - Földrajzi Közlemények 34. 4. pp. 475-482.

Kiss, T.-Sümeghy, B.-Hernesz, P.-Sipos, Gy.-Mezősi, G. 2013a. Az Alsó-Tisza menti ártér és a Maros hordalékkúp késő pleisztocén és holocén fejlődéstörténete. - Földrajzi Közlemények 137. 3. 269-277.

Kiss, T.-BlankA, V.-AndRÁsi, G.-Hernesz, P. 2013b. Extreme weather and the rivers of Hungary: rates of bank retreat. - In: Lóczy, D. (ed.): Geomorphological impacts of extreme weather: Case studies from Central and Eastern Europe. Springer, Dordrecht. 83-98

LAWLER, D.M. 1993: The measurement of bank erosion and lateral channel change: A review. - Earth Surface Processes and Landforms 18. 777-821.

Lawler, D.M.-Thorne, C.R.-Hooke, J.M. 1997: Bank erosion and instability. - In: Thorne, C.R.-Hey, R.D.-Newson, M.D. (eds.): Applied Fluvial Geomorphology for River Engineering and Management. Wiley, Chichester. pp. 137-172.

Lindow, N.-Fox, G.A.-Evans, R.O. 2009: Seepage erosion in layered stream bank material. - Earth Surface Landforms and Processes 34. 12. pp. 1693-1701. doi: 10.1002/esp.1874

LóCZy D. 2002: A folyóvizek felszínformálása. - In: Geomorfológia I. Földfelszíni folyamatok és formák. Dialóg Camus Kiadó, Budapest - Pécs. pp. 37-130.

LócZy D.-Kis É.-SchweITZER F. 2009: Local flood hazards assessed from channel morphometry along the Tisza River in Hungary. - Geomorphology 113. 3-4. pp. 200-209.

MONTGOMERY, D.R. 1997: What's best on banks? Nature 388. 328-329.

NAGY L.-TAKÁcs A. 2013: A 2013. évi dunai árvíz geotechnikai tapasztalatai. - In: SzLÁviK L. (szerk.): A 2013. évi dunai árvíz. Vízügyi Közlemények. Különszám, Budapest. pp. 299-318.

Naiman, R.J.-DeCamps, H.-McClain, M.E. 2005: Riparia: Ecology, Conservation, and Management of Streamside Communities. - Elsevier, Amsterdam

NRC 2002: Riparian Areas: Functions and Strategies for Management. - National Resource Council -National Academy Press, Washington, D.C.

PiÉgay, H.-Cuaz, M.-Javelle, E.-Mandier, P. 1997: Bank erosion management based on geomorphological, ecological and economic criteria on the Galuare River, France. - Regulated Rivers Research and Management 13. 433-448.

RATHBURN, B. 2012: BEHI modified for the state of Michigan. Integration of scores. - In: ENDRENY, T. (eds): Bank erosion Hazard Index Exercise. http://www.fgmorph.comfg_8_21.php

RóNAI A. 1972: Negyedkori üledékképződés és éghajlattörténet az Alföld medencéjében. - A MÁFIÉvkönyve 61. 1. 1-421.

RónAi A. 1985: Az Alföld negyedidőszaki földtana. Geologia Hungarica, Ser. Geol. 21. 1-446.

Rosgen, D.L. 2008: River Stability Field Guide. - Wildland Hydrology, Fort Collins, CO.

SCHWEITZER F. 2000: A magyarországi folyószabályozások geomorfológiai vonatkozásai: folyóink hullámtereinek fejlődése, kapcsolatuk az árvizekkel és árvízvédelmi töltésekkel. - Földrajzi Értesítő 50. 1-4. pp. 9-31.

SchweITZER, F. 2015: Strategy or disaster: New-style river regulation as an issue of national security. - Hungarian Geographical Bulletin 64. 4. pp. 307-315.

SCHweitzer F. 2017: Döntési kényszer a hazai árvízvédelemben. - In: Tanulmányok a geomorfológia, a geokronológia, a hidrogeográfia és a Mars-kutatás területéről. MTA CSFK Földrajztudományi Intézet, Budapest. pp. 103-135. (Elmélet-módszer-gyakorlat 73) 
Schweitzer F.-Nagy I. 2011. Döntési kényszer a hazai árvízvédelemben. - In: Schweitzer F. (szerk.): Katasztrófák tanulságai. Stratégiai jellegú természetföldrajzi kutatások. MTA Földrajztudományi Kutatóintézet, Budapest. pp. 13-48.

Simon, A.-Collinson, A. 2002: Quantifying the mechanical and hydrologic effects of riparian vegetation on stream bank stability. - Earth Surface Processes and Landforms 27. 527-546.

Sipos Gy.-Kiss T.-KoroKnai L.-Horváth Zs. 2009: Pleisztocén és holocén medrek vizsgálata az AlsóTiszavidéken. - In: 100 éves a Jégkorszak. Tudományos Konferencia, PTE TTK Földrajzi Intézet, Pécs

Stanford, J.A.-WARd, J.V.-Liss, W.J.-Frissell, C.A.-Williams, R.N.-Lichatowich, J.A.-Coutant, C.C. 1996: A general protocol for restoration of regulated rivers. - Regulated Rivers: Research and Management 12. 391-413.

TAKÁCS A.-KASZÁs F. 2013: Árvíz hatása a Duna parti felszínmozgásokra.-In: TOMPAi Z.-MAHLER A.-TAKÁCS A.-VARGA G. (szerk.): Geotechnika 2013 Konferencia, Ráckeve, 2013. október 15-16., Konferencia Iroda Bt., Budapest. Paper 21. p 10.

Thorne, C.R.-ToveY, N.K. 1981: Stability of composite river banks. - Earth Surface Processes and Landforms 6. 469-484.

WARD, J.V.-STANFORD, J.A. 1995: Ecological connectivity in alluvial river ecosystems and its disruption by flow regulation. - Regulated Rivers: Research and Management 11. 105-119.

WARD, J.V.-TOCKNER, K. 2001: Biodiversity: Towards a unifying theme for river ecology. - Freshwater Biology 46. 807-819. 